\title{
REDIMAT
}

Journal of Research in Mathematics Education

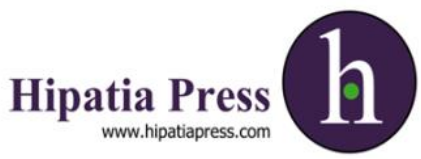

Instructions for authors, subscriptions and further details:

http://redimat.hipatiapress.com

\section{Mathematics Teacher Education in Turkey through the Lens of International TEDS-M Study}

Güneş Ertaş ${ }^{1}$, Fatma Aslan-Tutak ${ }^{1}$

1) Bogazici University, Turkey

Date of publication: June $24^{\text {th }}, 2021$

Edition period: June-October 2021

To cite this article: Ertaş, G., and Aslan-Tutak, F. (2021). Mathematics teacher education in Turkey through the lens of international TEDS-M study. REDIMAT - Journal of Research in Mathematics Education, 10(2), 152-174. doi: $10.17583 /$ redimat.2021.3627

To link this article: http://dx.doi.org/10.17583/redimat.2021.3627

\section{PLEASE SCROLL DOWN FOR ARTICLE}

The terms and conditions of use are related to the Open Journal System and to Creative Commons Attribution License (CCAL). 
REDIMAT, Vol. 10 No. 2 June 2021 pp. 152-174

\title{
Mathematics Teacher Education in Turkey through the Lens of International TEDS-M Study
}

\author{
Güneş Ertaş \\ Fatma Aslan-Tutak \\ Bogazici University \\ Bogazici University
}

(Received: 10 July 2018; Accepted: 07 April 2021; Published: 24 June 2021)

\section{Abstract}

This paper is a part of a broader study which aims to investigate mathematics teacher candidates' mathematical knowledge for teaching (MKT) by using the Turkish translated versions of TEDS-M (Teacher Education and Development Study in Mathematics) Primary and Secondary Released Items. The sample of the study comprised freshman (first year) and senior (fourth and fifth year) students from primary and secondary mathematics teacher education programs. Firstly, this study aimed to examine differences in MKT of teacher candidates at the beginning and at the end of their undergraduate education. For both departments, senior students had statistically significant higher scores than freshman students. Secondly, this study also aimed to examine participating Turkish preservice mathematics teachers' mathematical knowledge for teaching by using international results of TEDS-M Study. Participating senior preservice teachers' correct response percentages were higher than international average in all domains except "data" in primary level, and "data", "mathematical modelling" and "symmetry" in secondary level. The common content domains where primary and secondary preservice teachers" percentages were lower than international average is "data". In this paper, these areas will be examined within the context of Turkish education.

Keywords: Pre-service Mathematics Teacher, Mathematical Knowledge for Teaching (MKT), Teacher Education and Development Study in Mathematics (TEDS-M), Teacher Training in Turkey 


\section{Formación de Profesores de Matemáticas en Turquía a través de la Lente del Estudio Internacional TEDS-M}

Güneş Ertaş Bogazici University
Fatma Aslan-Tutak

Bogazici University

(Recibido: 10 Julio 2018; Aceptado: 07 Abril 2021; Publicado: 24 Junio 2021)

\section{Resumen}

Este documento es parte de un estudio más amplio cuyo objetivo es investigar el conocimiento matemático para la enseñanza (MKT) de los candidatos a profesor de matemática utilizando las versiones traducidas turcas de TEDS-M (Teacher Education and Development Study in Mathematics) las preguntas del cuestionario primarios y secundarios publicados. La muestra del estudio estuvo compuesta por estudiantes de primer año y estudiantes de último año de programas de formación de matemáticas primarias y secundarias. Este estudio tuvo como objetivo examinar las diferencias en MKT de los futuros maestros de primer y último año de universidad. Para ambos casos, los estudiantes de último año tuvieron puntajes estadísticamente más altos que los estudiantes de primer año. Los porcentajes de respuesta correctos de los candidatos de profesores de ultimo año fueron más altos que el promedio internacional en todos los dominios excepto en los ámbitos de "datos" (primaria y secundaria) y, "modelado matemático" y "simetría" (secundaria).

Palabras clave: Profesor de Matemáticas en formación, Conocimiento Matemático para la Enseñanza (MKT), TEDS-M, Formación de Profesorado en Turquía 
he main concern of studying mathematics teacher knowledge is not to prepare teachers who know more mathematics but to improve students' learning and understanding of mathematics (Ball, 2003). Student's learning occurs through the experiences that teachers provide in class, so it can be said that the improvement of student's learning depends on effective mathematics teaching (NCTM, 2000). Teachers' knowledge and competencies are at the core of effective teaching (Walshaw, 2012). The foundations of teachers' knowledge are laid in teacher education programs, and upon graduation, teachers start to teach with the knowledge they have attained in undergraduate years. In this study, the authors explored mathematical knowledge for teaching of participating Turkish middle and high school mathematics teacher candidates. Mathematical knowledge for teaching is defined as encompassing both subject matter knowledge and pedagogical content knowledge.

\section{Teacher Education in Turkey}

In Turkey, there may be a never-ending discussion around who will be teachers and how teachers will be trained. Almost every new government, with the new period, has worked on educational reforms which include teacher education policies. In Turkey, the history of teacher education shows that there is not a consistent policy that has been pursued in teacher education (Özoğlu, Gür, \& Çelik, 2010). Until 1982, the Ministry of Education and universities were responsible for teacher education. Teacher schools and education institutes provided training for teacher candidates. However, in those years there was a teacher shortage problem so in addition to teacher schools and institutes, teachers were employed through some other short-term methods such as reserve officer teachers, teacher education through letters and temporary teachers (after education courses). In 1982, the law had changed, and faculties of education were established in universities and only universities were responsible for teacher education. To be a teacher, candidates had to complete undergraduate education programs in teacher education. Today, universities still educate teachers but since 1982, Council of Higher Education (CHE) 
made four important reforms (in 1989, 1997, 2006 and 2010). With these reforms, the structure of the teacher education and the teacher hiring policies changed. From time to time, when a teacher shortage occurred, in addition to graduates of faculty of education, graduates of other faculties had the chance to become teachers providing that they completed the necessary teaching certificate program. With the change in 2010; CHE granted graduates from faculties of art and sciences the right to become teachers after completing teaching certificate programs. For example, graduates of undergraduate program in mathematics have a right to be mathematics teachers if they take the teaching certificate. In order to improve students' scores and adapt to 21 st century needs, there have always been reform movements in teacher education in Turkey as well as reforms in national curriculums. In 2018, the Ministry of Education announced 2023 Vision Document addressing a wide range of topics with the main focus on evidence-based decision making (Milli Eğitim Bakanlığı, 2018). Teacher practices and continuous teacher education was also one of the dimensions of this document because policymakers are aware that changing national curriculums alone is not enough to improve students' scores. The Ministry of Education (2018) has also suggestions for preservice teacher education programs to be improved to include more classroom practice time. All things considered, there have been many attempts to improve teacher qualifications in Turkey. Yet one last aspect of teacher education is the policy of teacher assignments. In the past, there was a teacher shortage problem but nowadays there is a teacher surplus problem and supply-demand disequilibrium. Therefore, teacher candidates are in a big competition to be assigned as teachers to public schools. Graduation from teacher education programs or completing teaching certificate programs is not enough to be teachers in public schools, candidates must also take an exam. Since 1999, teacher candidates have to take an exam (like Praxis, in USA) to be hired in public schools: Public Personnel Selection Examination (PPSE). PPSE test questions were from the following areas and given weight in calculation of a teacher's score: General ability \%30, Liberal education \%30, Educational sciences $\% 40$. Educational sciences area consisted of questions from educational psychology, curriculum development, teaching methods, 
assessment and evaluation, and guidance. Because of the severe criticisms about the exam, in 2013, it was revised to include content knowledge $(80 \%)$ and pedagogical content knowledge (20\%) questions for 13 subject areas. The main purpose of the exam is the assignment of teachers, but it can be said that teacher knowledge is also trying to be measured. Research shows that teacher knowledge positively related with students' learning (Peterson, 1998) and it may be an indicator for students' achievement (Hill, Rowan \& Ball, 2005). Therefore, it is important to investigate what teachers know before they start to teach. In before teaching period, it can be said that teacher candidates develop their content and pedagogical content knowledge in their undergraduate years. Once they become teachers, this knowledge continues to develop through teaching. However, it should be noted that the stronger these foundations are laid, the better teachers can build new knowledge in practice (Ball, Lubienski, \& Mewborn, 2001). Therefore, how preservice teachers develop their knowledge in their undergraduate education is important because they will build new knowledge on their existing knowledge.

\section{Teacher Knowledge}

According to Shulman (1986), teachers' knowledge comprises subject matter knowledge (SMK), pedagogical content knowledge (PCK) and curricular knowledge. His conceptualization illuminated the whole field of education. In the field of mathematics education, as a refinement of Shulman's model, there exists a promising and widely used model: Mathematical Knowledge for Teaching (MKT) model which has been developed by Ball and her colleagues (2008). Based on Shulman's categorization of SMK and PCK, Ball and her colleagues (2008) defined sub-categories of SMK (common content knowledge, specialized content knowledge, and horizon content knowledge) and PCK (knowledge of content and students, knowledge of content and teaching and knowledge of curriculum) specifically for teaching mathematics.

During teacher education programs, preservice mathematics teachers would have chances to improve both their SMK and PCK. 
Both in primary mathematics education and secondary mathematics education departments, students take several theoretical and methodological courses which enable them to improve their knowledge of mathematics and knowledge of teaching mathematics. In teaching methods and practicum courses, for example, they discuss and experience school mathematics that they will teach. Therefore, as teacher candidates, they have a chance to reconsider and relearn school mathematics. Teaching related courses provide preservice teachers an opportunity to unpack their knowledge and ask why and how questions on school mathematics topics.

There are several studies on the issue of mathematics teachers' knowledge which aim to investigate and develop teachers' SMK and PCK. Researchers point out the necessity to enhance teachers' SMK in undergraduate years (Ubuz \& Yayan, 2010), as well as the needs to unpack the mathematical knowledge in order to make it teachable and understandable for students (Aslan-Tutak, 2012). These studies also show that preservice teachers have difficulties in identifying the source of students' mistakes and misconceptions and how to deal with them (Kilıç, 2010; Bingolbali, Akkoc, Ozmantar, \& Demir, 2011; Durakkaya, Aksu, et al., 2011). Based on their SMK and PCK, teachers design mathematics that will be done in class and students will interact and think about. It should be underlined that when studying teacher knowledge, the purpose is not to prepare teachers who know more mathematics, the main focus and the goal is to improve students' learning (Ball, 2003).

Comparing preservice mathematics teacher knowledge with other countries' preservice teachers may also be used to interpret low student outcomes on international tests. In Turkey, students' scores were low compared to other countries in the international assessments Trends in International Mathematics and Science Study (TIMSS) and Programme for International Student Assessment (PISA). Walshaw (2012) discusses that the knowledge and competencies that a teacher has lie at the core of the effective teaching. In addition, NCTM (2000) addresses the need for "effective mathematics teaching in all classrooms" (p. 16) as a requirement for improving students' mathematics learning. 
Even though it may seem evident that a knowledgeable teacher will do a better job in effective instruction, in order to investigate such relationship, it is necessary to measure teachers' knowledge. However, it is not easy to measure such a complex concept (Wilson, 2007). Particularly in mathematics education, there are several studies and research projects that aim to develop instruments to measure teachers' mathematics content knowledge for teaching (Ball, Thames, \& Phelps, 2008; Krauss, Baumert, \& Blum, 2008; Tatto et al., 2008). Among them The Teacher Education and Development Study in Mathematics (TEDS-M) stands out as being designed for an international and comparative study for both primary and secondary preservice mathematics teachers by Tatto and her colleagues. The primary and secondary instruments that were developed for TEDS-M cover the content and cognitive domains of primary and secondary level mathematics. The items were designed to measure mathematics content knowledge and mathematics pedagogical content knowledge. Tatto and her colleagues did not develop the instruments countryspecific, but they designed them for international usage and national adaptations.

Therefore, in order to investigate mathematics teacher candidates' mathematical knowledge for teaching, TEDS-M items can be suitable for the purpose of this study. The purpose of the main study was to adapt TEDS-M measurements to Turkish (Ertas \& Aslan-Tutak, 2017) and to investigate the knowledge of teacher candidates by comparing them both according to their years of study in university and the departments that they are studying in. In this paper, the comparison according to years of study is discussed considering teacher education in Turkey. Moreover, since the average percentage of item-by-item correct responses of international participants (as international average of 17 countries) of TEDS-M study were shared with TEDS-M released items documents, the study had the chance to discuss about the position of Turkish participants of mathematics teacher candidates according to the international average of mathematics teacher candidates. 


\section{Methods}

\section{Sampling and Participants}

In Turkey, at the time of the study, there were 14 universities that have both primary and secondary mathematics teacher education departments. For this study, for accessibility reasons, universities located in Istanbul were participant universities. In Istanbul there are two universities that have both primary mathematics teacher education and secondary mathematics teacher education departments. So, the study participants were these two universities' freshman (first year) and senior students (last year: fourth or fifth year) who were studying primary mathematics teacher education and secondary mathematics teacher education. For the main study, it was not possible to follow freshman students' progresses during their study until they graduated, so cross-sectional design is used. It allows comparing different population groups at a single point in time. In this study, freshman and senior students were different students. The instruments were given to all freshman students who were enrolled in first year mathematics course and senior students who were enrolled in last semester teaching methods courses. There were 90 freshmen 50 senior voluntary participants from primary mathematics teacher education department who would teach in grades 4-8 and 27 freshmen and 47 senior participants from secondary mathematics teacher education department who would teach in 8-12 grade levels.

\section{Instruments}

For the purpose of the study, TEDS-M items were appropriate instruments because they cover the content and cognitive domains of primary and secondary level mathematics separately. However, Turkey was not one of the participant countries of TEDS-M, so the instrument was neither adapted in Turkish nor applied in Turkey until this study was conducted. As a result of the study, these measures were translated into Turkish and adapted to be used in Turkish (Ertas \& Aslan-Tutak, 2017). The main purpose of the broader study was to 
investigate the mathematical content and pedagogical content knowledge of mathematics teacher candidates. In accordance with this purpose, Turkish translated versions of TEDS-M Primary and Secondary Level Instruments were used.

As a part of TEDS-M study these instruments were developed to measure pre-service teachers' knowledge of mathematics content and pedagogical content for teaching at the end of their teacher education. These instruments consist of mathematical content knowledge (MCK) and mathematics pedagogical content knowledge (MPCK) items. These items were developed by TEDS-M researchers considering the framework of Trends in International Mathematics and Science Study (TIMSS) 2007 (Tatto et al., 2008). MCK items consisted of four content areas: number, algebra, geometry and data, whereas it has three cognitive dimensions: knowing, applying, and reasoning. These content areas and cognitive domains were adapted from TIMSS 2007 framework. Furthermore, MPCK items consisted of two parts: knowledge of curricula planning and interactive knowledge about how to enact mathematics for teaching and learning. These were aligned with PCK domains in literature. Three different item formats were used: Multiple Choice (MC), Complex Multiple Choice (CMC), and Open Constructed Response (CR). Below tables show the distribution of MCK and MPCK items for primary and secondary instruments separately.

Table 1.

Primary Instrument MCK Items

\begin{tabular}{lccccc}
\hline \multirow{2}{*}{ Cognitive Domain } & \multicolumn{5}{c}{ Content Domain } \\
& Algebra & Geometry & Number & Data & Total \\
\hline Knowing & 7 & 3 & 5 & 0 & 15 \\
Applying & 3 & 3 & 1 & 1 & 8 \\
Reasoning & 0 & 0 & 0 & 1 & 1 \\
Total & 10 & 6 & 6 & 2 & 24 \\
\hline
\end{tabular}


160 Ertaş \& Tutak-Mathematics Teacher Education in Turkey

Table 2.

Primary Instrument MPCK Items

Content Domain

\begin{tabular}{lccccc} 
& Algebra & Geometry & Number & Data & Total \\
\hline Curriculum \& Planning & 1 & 2 & 2 & 1 & 6 \\
Enacting & 1 & 0 & 2 & 1 & 4 \\
Total & 2 & 2 & 4 & 2 & 10 \\
\hline
\end{tabular}

Table 3.

Secondary Instrument MCK Items

Content Domain

Cognitive Domain

Algebra Geometry Number Data Total

\begin{tabular}{lccccc}
\hline Knowing & 0 & 2 & 4 & 0 & 6 \\
Applying & 5 & 4 & 0 & 1 & 10 \\
Reasoning & 2 & 1 & 4 & 0 & 7 \\
Total & 7 & 7 & 8 & 1 & 23 \\
\hline
\end{tabular}

Table 4.

Secondary Instrument MPCK Items

Content Domain

\begin{tabular}{lccccc} 
& Algebra & Geometry & Number & Data & Total \\
\hline Curriculum \& Planning & 4 & 0 & 0 & 0 & 4 \\
Enacting & 1 & 0 & 3 & 1 & 5 \\
Total & 5 & 0 & 3 & 1 & 9 \\
\hline
\end{tabular}

\section{Turkish translation}

Teacher education and the work of teaching differ from country to country, so measurement of teacher knowledge needs to be sensitive to these differences (Delaney et al., 2008). For the international study of TEDS-M, researchers used translation and adaptation guidelines of TIMSS in order to provide equivalence of national versions (Tatto et 
al., 2008). These guidelines were also followed for the Turkish translations of TEDS-M items by the authors.

The translations of both levels, primary and secondary, of instruments was conducted in three phases. Firstly, items were translated into Turkish by the researcher who is fluent in English. The translated documents were reviewed by a mathematics educator who is an expert in the content area and fluent in English, a three-year experienced mathematics teacher who is fluent in English, and a professional translator. According to their reviews and comments, all items were checked in detail and the revisions of translation was completed. In the second phase, as a pilot study the original tests were administered on a group of preservice mathematics teachers who are native in Turkish and fluent in English. The same group took the Turkish translated versions of the tests 3 weeks apart from the originals. The results were compared, and the translation was revised. Lastly, the method of back translation was used to check the quality of translation and to investigate linguistic or conceptual errors in translation. It was also used to pay particular attention to sensitive translation problems across cultural correspondence of the two versions. After the back translation, Turkish translated TEDS-M primary and secondary level items were finalized (Ertas \& AslanTutak, 2017).

\section{Data Collection and Data Analysis}

The data was collected from participants at a single point in two different time periods. Senior students' data was collected at the end of spring semester of 2012-2013 academic year (just before their graduation) and the data was collected from freshman students at the beginning of fall semester of 2013-2014 academic year. The instruments were given students during class time and voluntary ones answered the items.

The items are made up of three different formats: multiple choice, complex multiple choice, and open constructed response. The openended items were scored according to the scoring guide of TEDS-M Primary and Secondary Instruments. Freshman and senior 
participants' performances were compared by using appropriate statistical methods. Not only items and scoring guide, but also item by item correct response percentages from international data are shared within the instruments. Using this information, the item-by-item correct response percentages were calculated for the current participants and they were analyzed descriptively by comparing international averages. Then, they are used to examine the position of Turkish participants for each item and each content domain.

\section{Results}

The participants' performances in TEDS-M items were compared according to their status (freshman vs. senior) for primary and secondary level separately. For both primary and secondary levels, the statistical test results show that there is a significant difference between freshman and senior students in scores. In primary level, the seniors' score ( $\mathrm{n}=50, \mu=31.96, \mathrm{SD}=3.49)$ is significantly higher than freshmen's score $(\mathrm{n}=90, \mu=28.80, \mathrm{SD}=3.35)$, t $(138)=5.27$, $\mathrm{p}<.001$ with the effect size Cohen's $d=.92$. Similarly, for secondary level, senior students $(\mathrm{n}=25, \mu=28.88, \mathrm{SD}=2.96)$ have significantly 6.84 points higher mean score than freshman students $(\mathrm{n}=27, \mu=$ 22.04, $\mathrm{SD}=2.72), \mathrm{t}(50)=8.68, \mathrm{p}<.001$ and Cohen's $\mathrm{d}=2.41$ shows strongly large effect (Cohen, 1988).

Moreover, the item-by-item correct response percentages of the participants and the international average were analyzed descriptively. For primary and secondary level separately, TEDS-M released average of correct response percentages of all items for all participants from 17 countries. Similarly, the correct response percentages of this study's participants were calculated and evaluated by comparing with the international results. Table 5 shows all items and correct response percentages of participants and international averages for both primary and secondary levels. 
Table 5.

Correct Response Percentages

\begin{tabular}{|c|c|c|c|c|c|}
\hline \multicolumn{3}{|c|}{ Primary } & \multicolumn{3}{|c|}{ Secondary } \\
\hline items & international & $\begin{array}{c}\text { participants } \\
\text { (primary) }\end{array}$ & items & international & $\begin{array}{l}\text { participants } \\
\text { (secondary) }\end{array}$ \\
\hline 1 & 28 & 88 & 1a1 & 72 & 100 \\
\hline 2 & 28 & 50 & $1 \mathrm{a} 2$ & 50 & 98 \\
\hline $3 a$ & 81 & 98 & $1 b$ & 50 & 72 \\
\hline $3 b$ & 86 & 96 & $2 \mathrm{a}$ & 44 & 94 \\
\hline $3 \mathrm{c}$ & 92 & 100 & $2 b$ & 54 & 89 \\
\hline $3 d$ & 64 & 70 & $2 \mathrm{c}$ & 37 & 62 \\
\hline 4 & 67 & 96 & 3 & 53 & 91 \\
\hline 5 & 61 & 86 & 4 & 57 & 100 \\
\hline $6 a$ & 78 & 100 & $5 \mathrm{a}$ & 53 & 81 \\
\hline $6 \mathrm{~b}$ & 54 & 68 & $5 b$ & 51 & 83 \\
\hline $7 \mathrm{a}$ & 32 & 60 & $6 a$ & 75 & 94 \\
\hline $7 \mathrm{~b}$ & 32 & 46 & $6 b$ & 46 & 87 \\
\hline 8 & 82 & 90 & $6 c$ & 60 & 77 \\
\hline 9 & 54 & 98 & $7 \mathrm{a}$ & 41 & 32 \\
\hline $10 \mathrm{a}$ & 78 & 100 & $7 \mathrm{~b}$ & 39 & 68 \\
\hline $10 \mathrm{~b}$ & 52 & 68 & $7 \mathrm{c}$ & 60 & 75 \\
\hline 11 & 49 & 96 & 8 & 19 & 43 \\
\hline 12 & 38 & 86 & $9 \mathrm{a}$ & 78 & 87 \\
\hline 13 & 60 & 82 & $9 b$ & 78 & 87 \\
\hline 14 & 67 & 46 & $9 \mathrm{~d}$ & 64 & 70 \\
\hline $15 \mathrm{a}$ & 56 & 100 & $10 \mathrm{a}$ & 46 & 83 \\
\hline $15 b$ & 51 & 98 & $10 \mathrm{~b}$ & 63 & 77 \\
\hline 16 & 85 & 100 & $10 \mathrm{c}$ & 58 & 96 \\
\hline $17 \mathrm{a}$ & 85 & 94 & $10 \mathrm{~d}$ & 54 & 66 \\
\hline $17 \mathrm{~b}$ & 74 & 44 & 11 & 35 & 85 \\
\hline $18 \mathrm{a}$ & 74 & 78 & $12 \mathrm{a}$ & 71 & 83 \\
\hline
\end{tabular}


164 Ertaş \& Tutak-Mathematics Teacher Education in Turkey

Table 5. (Continue)

Correct Response Percentages

\begin{tabular}{cccccc}
\hline & Primary & & & Secondary \\
items & international & $\begin{array}{c}\text { participants } \\
\text { (primary) }\end{array}$ & items & international & $\begin{array}{c}\text { participants } \\
\text { (secondary) }\end{array}$ \\
\hline $18 \mathrm{~b}$ & 89 & 100 & $12 \mathrm{~b}$ & 69 & 64 \\
$18 \mathrm{c}$ & 69 & 88 & $13 \mathrm{a}$ & 70 & 85 \\
$18 \mathrm{~d}$ & 42 & 100 & $13 \mathrm{~b}$ & 61 & 87 \\
19 & 97 & 96 & $13 \mathrm{c}$ & 53 & 32 \\
20 & 74 & 100 & 14 & 21 & 77 \\
21 & 33 & 76 & & & \\
22 & 38 & 80 & & & \\
23 & 48 & 54 & & & \\
\hline
\end{tabular}

Below charts show the comparison of primary mathematics teacher candidates \& TEDS-M primary international averages (Figure 1) and secondary mathematics teacher candidates \& TEDS-M secondary international averages (Figure 2).

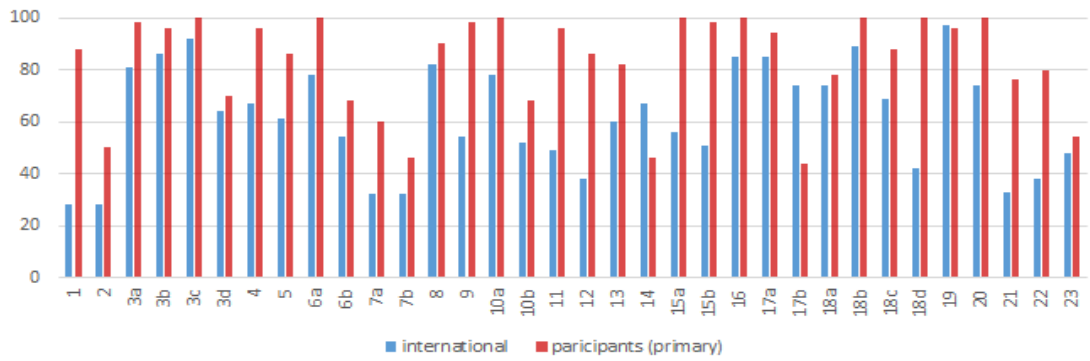

Figure 1. Correct Response Percentages in Primary Level

For primary level, at first glance, it can be said that participants' correct response percentages are higher than international average. For 23 of 34 items, more than $80 \%$ of participants gave correct answer. Among these 23 items, 8 items (Item 3c, 6a, 10a, 15a, 16, 18b, 18d, $20)$ were answered correctly by all of the participants. 
On the other hand, the data indicates that for 3 items among 34, participants' correct response percentage is lower than international average. These three items are 14, 17b and 19. For item 19, since the percentage of international average is 97 and current study's participants' average is 96 , the results are close to each other. However, for item 14 and item $17 \mathrm{~b}$, the differences in percentage are 21 (67\% vs. $46 \%)$ and 30 (74\% vs. $44 \%)$, respectively.

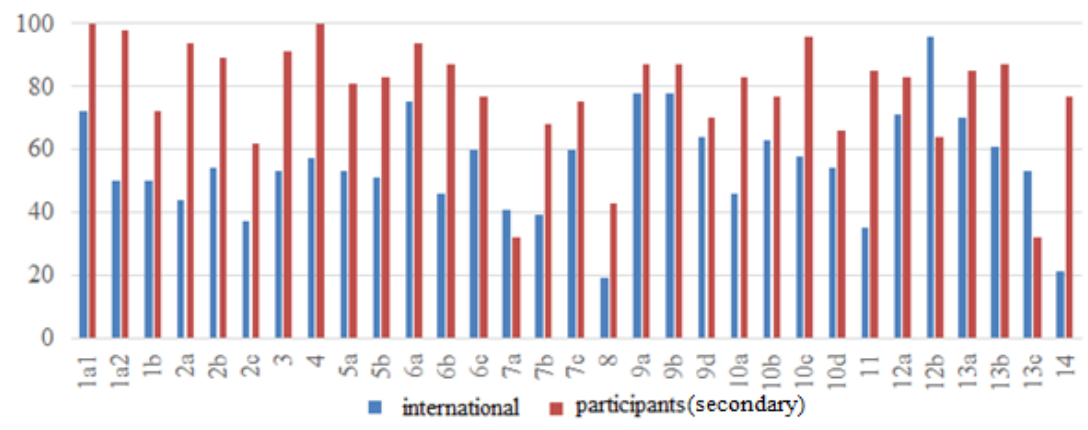

Figure 2. Correct Response Percentages in Secondary Level

For secondary level, it is the same as the primary in those the participants' correct response percentages are higher than international average. Also, for 18 items more than $80 \%$ of them gave correct answer and all of the participants answered 2 items correctly (Item 1a1, 4) among these 18 items.

Moreover, only for 3 items over 31 , the correct response percentage of participants is lower than international average. These three items are $7 \mathrm{a}, 12 \mathrm{~b}$ and $13 \mathrm{c}$ and the difference in percentages between international average and participants are 9 (41\% vs. 32\%), 5 (69\% vs. $64 \%)$ and 21 (53\% vs. $32 \%)$, respectively.

\section{Discussion}

In order to see the contribution of undergraduate programs on teacher candidates' mathematical knowledge for teaching (MKT), freshman and senior students' TEDS-M scores were compared in primary and 
secondary levels separately. The statistical analysis showed that for all groups of participants from the two departments, there were significant differences between freshman and senior students in their performances. The undergraduate education in these departments may contribute to improving MKT of teacher candidates. In order to explain departments' contribution on MKT, curricula of the departments were examined.

In Turkey, during the teacher education programs in primary mathematics education and secondary mathematics education departments, students take several theoretical and methodological courses which enable them to improve their knowledge of mathematics and knowledge of teaching. Primary mathematics education departments' teacher education programs include 50-60\% content knowledge and skills, 25-30\% professional teaching knowledge and skills, and 15-20\% general knowledge courses (Yüksek Öğretim Kurumu-YÖK, 2007). In secondary mathematics education departments, students are required to complete $50 \%$ content knowledge and skills, 30\% professional teaching knowledge and skills, and $20 \%$ general knowledge courses.

In teacher education programs, students take teaching methods, general pedagogy and practicum courses. In teaching methods and practicum courses they discuss and experience school mathematics that they will teach. Therefore, as teacher candidates, they have a chance to reconsider and relearn school mathematics. Teaching related courses provide preservice teachers an opportunity to unpack their knowledge and ask why and how questions on high school mathematics topics. Therefore, for participants from primary mathematics education and secondary mathematics education departments the difference in scores between freshman and senior students may be explained by teacher education programs.

Another purpose of the study is to investigate the participants' position according to TEDS-M international item by item correct response percentages results. TEDS-M was conducted in 2008 and Turkey was not a participating country. TEDS-M researchers reported the results based on the data from 17 participating countries and the data shows international average of item-by-item correct responses percentages (TEDS-M International Study Center, 2009). This data 
gives us a chance to analyze the international data with the present study descriptively. The item-by-item correct responses for both groups are showed graphically in results section (Figure $1 \& 2$ ).

According to results for primary and secondary levels, participants' correct response percentages are lower than TEDS-M averages for 5 items in total. These items have some common characteristics. Three of them are from the content domain "data" and pedagogical content knowledge dimension. The other two are content knowledge items from the algebra and geometry content domains and applying subdomains. Table 6 shows the characteristics of these 5 items and the percentages for participant and TEDS-M international average.

Table 6.

Items Characteristics

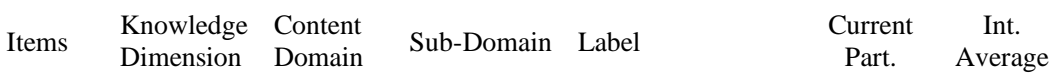

\begin{tabular}{|c|c|c|c|c|c|c|c|}
\hline \multirow{2}{*}{ 胥 } & 14 & MPCK & Data & Enacting & $\begin{array}{l}\text { Similarities and } \\
\text { differences in data } \\
\text { presentation }\end{array}$ & $46 \%$ & $67 \%$ \\
\hline & $17 b$ & MPCK & Data & $\begin{array}{l}\text { Curric and } \\
\text { Plan }\end{array}$ & $\begin{array}{l}\text { Difficulty with a } \\
\text { data representation } \\
\text { problem }\end{array}$ & $44 \%$ & $74 \%$ \\
\hline \multirow{3}{*}{ 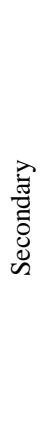 } & $7 \mathrm{a}$ & MCK & Algebra & Applying & $\begin{array}{l}\text { Determine whether } \\
\text { a situation can be } \\
\text { modeled by an } \\
\text { exponential } \\
\text { function. }\end{array}$ & $32 \%$ & $41 \%$ \\
\hline & $12 b$ & MPCK & Data & Enacting & $\begin{array}{l}\text { Explain student's } \\
\text { thinking about } \\
\text { histogram }\end{array}$ & $64 \%$ & $69 \%$ \\
\hline & $13 \mathrm{c}$ & MCK & Geometry & Applying & $\begin{array}{l}\text { Correct students' } \\
\text { answers about lines } \\
\text { of symmetry in a } \\
\text { rhombus. }\end{array}$ & $32 \%$ & $53 \%$ \\
\hline
\end{tabular}

The content domain of the items 14 and $17 \mathrm{~b}$ from primary level and the item $12 \mathrm{~b}$ from secondary level are "data". Three of them refer to 
pedagogical content knowledge. Item 14 requires finding the similarities and differences in data presentation and item $17 \mathrm{~b}$ requires determining difficulty with a data representation problem and the item $12 \mathrm{~b}$ requires explaining student's thinking about histogram.

The results of the study show that both primary and secondary preservice teachers' correct response percentages are lower in the content domain "data" compared to the remaining items. Furthermore, according to TIMSS 2011 report, in Turkey, mathematics teachers of eight graders thought that they were less qualified in the content domain of data and chance compared to other content domains (Yıldırım, Yıldırım, Ceylan, \& Yetişir, 2013).

The reason for this insufficiency in the content domain "data" may be due to the fact that they had limited learning experience with Data Display, Data Interpretation or Data Analysis concepts. When the participants of the study were in middle or high school, these concepts were not included in the mathematics curriculum. In university, statistics and probability courses are obligatory for primary mathematics education department. Although, teacher candidates took these courses, it might not have provided students with opportunities to improve their statistics and data skills.

In secondary level, apart from the data content domain item $12 \mathrm{~b}$, participants' correct response percentages are lower than international average for the items $7 \mathrm{a}$ and $13 \mathrm{c}$ that are from the content domains algebra and geometry, respectively. Item 7a is content knowledge item which is required to determine whether a situation "the height $\mathrm{h}$ of a ball $t$ seconds after it is thrown into the air" can be modeled by an exponential function. Item $7 \mathrm{a}$ is one of the sub-questions of question 7. Question 7 is a complex multiple-choice question, and it requires to mark for each item under the question. The other two items required to determine whether a situation "the amount of money A in a bank after w weeks, if each week d zeds are put in the bank" (item 7b) and "the value $\mathrm{V}$ of a car after $t$ years if it depreciates $d \%$ per year" (item 7c) can be modelled by an exponential function. Participants' performances in item $7 \mathrm{~b}$ and item $7 \mathrm{c}$ are higher than international level. While $32 \%$ of participants response correctly item $7 \mathrm{a}$, approximately $\% 72$ of them mark the correct response for item $7 \mathrm{~b}$ and item 7c. The difference of these items is that participants are familiar 
with these kind of problems from their secondary school years. However, item 7 a requires modeling in the physics context.

Similar to reason for data content domain, the reason behind the lower performances in mathematical modeling item may lie in the high school years of participants (Ertas \& Aslan-Tutak, 2015) When the curriculum developments in Turkey are considered, it is seen that mathematical modeling has started to be implemented in high schools after the curriculum reform in 2013. Therefore, the participants may have limited experience for mathematical modelling in their high school years and this situation may reflect their content knowledge.

The other item in which secondary participants' correct response percentages are lower than international, is geometry-applying question. The complex multiple-choice question asks the number of symmetry lines of regular hexagon, regular pentagon and rhombus in separate items. Among them, correct response percentage of the item that asks symmetry lines of rhombus is lower than other items and the international average. In Turkish setting, a study about the preservice mathematics teachers' understanding of symmetry lines of polygons shows that they may have difficulty in describing symmetry lines especially for parallelogram (Hacısalihoglu Karadeniz, Baran, Bozkuş and Gündüz, 2015).

Yet there is still a question that remains unanswered from this study: Why preservice teachers have higher scores than international results in spite of low student achievement scores of Turkey. One explanation for this discrepancy may come from the challenge of measuring teacher knowledge. Even though TEDS-M items were developed for measuring preservice teachers' mathematical knowledge for teaching, it has fewer items related to classroom settings and more items which are mathematical questions. As authors of this manuscript discussed before (Ertas \& Aslan-Tutak, 2015), measuring teacher knowledge is a challenge in mathematics teacher education studies. The surprising result of misalignment between students' scores from international tests and preservice teacher knowledge scores from this study would lead to a discussion of how to measure teacher knowledge and how to develop more items bringing the complexity of classroom practice to tests. 
Another explanation for this discrepancy may come from the time needed for Turkish teacher education movements to affect classroom practices. There have been several attempts to improve teacher education in Turkey hoping to change classroom practices and improve student scores on international tests. For example, there is a regulation requiring that students to be enrolled in teacher education programs must score within a certain percentile on the university entrance exam, which also means that Turkish preservice teachers are performing well on high-stake tests. In Turkey, in spite of curricular movements to improve student scores on international tests, enacted curriculum is focused on national high school placement and university entrance exams (Mercan, 2013). Since high school graduates need to score well in order to enter a teacher education program, the participants of this study may be good at test-taking. In addition to this enrollment requirement, the teacher education programs, and courses also have been subject to improvements. Turkish teacher educators are hoping for gradual change to happen as the reforms in teacher education starts to influence classroom practices. Lastly, the authors would like to add that in this study, the participants were from two public universities in Istanbul that are among the 5 highest ranking universities of Turkey for primary and secondary mathematics education. Students at those universities had to score high in university entrance exam. Therefore, the finding that they scored higher than the international average is expected.

Thus, the implication from this research is twofold, improving teacher educators' tools for assessing teacher knowledge, and implementing further content reforms in Turkish teacher education. The conflicting result of high preservice teacher scores with low international student scores may be used to examine how teacher knowledge is measured, with less connection to classroom practices. Even though teacher knowledge test scores may correlate with students' scores for other countries, this connection needs to be examined further for Turkish context. Secondly, it's important to note that even higher achieving participating mathematics teacher candidates could not perform well on some items. In five items their performances are lower than international average. If the possible reasons behind the low performances are considered, then participants' 
limited experience with these content areas appears. The significant difference between freshman and senior participants indicated that teacher education programs are effective in improving teacher candidates' knowledge. But there are still some areas which have issues that teacher education needs to address. This result may have implications for not only teacher education curriculum but also national curriculum to address statistics. Turkish national curriculum and teacher education curriculum needs to be improved in order to address 21 st century requirements for statistics education.

\section{References}

Aslan-Tutak, F. (2012). Preservice secondary school mathematics teachers' specialized content knowledge of complex numbers. In The proceedings of the $12^{\text {th }}$ international congress on mathematical education (ICME 12). Seoul, Korea.

Ball, D. L., Lubienski, S., \& Mewborn, D. (2001). Research on teaching mathematics: The unsolved problem of teachers' mathematical knowledge. In V. Richardson (Ed.), Handbook of research on teaching (4th ed., pp. 433-456). Macmillan.

Ball, D. L. (2003). What mathematical knowledge is needed for teaching mathematics?

http://deimos3.apple.com/WebObjects/Core.woa/DownloadTra ckPreview/tamu-ublic.211769 9024.02117699032 .2276247151.pdf

Ball, D. L., Thames, M. D., \& Phelps, G. (2008). Content knowledge for teaching: What makes it special? Journal of Teacher Education, 59(5), 389-407. https://doi.org/10.1177/0022487108324554

Bingölbali, E., Akkoç, H., Özmantar, M. F. \& Demir, S. (2011). Preservice and in-service teachers' views of the source of students' mathematical difficulties. International Electronic Journal of Mathematics Education, 6(1), 40-59.

Cohen, J. (1988). Statistical power analysis for the behavioral sciences (2nd ed.). Erlbaum Associates.

Delaney, S., Ball, D. L., Hill, H. C., Schilling, S. G., \& Zopf, D. 
(2008). "Mathematical knowledge for teaching": adapting U.S. measures for use in Ireland. Journal of Mathematics Teacher Education, 11(3), 171-197.

Durakkaya, M., Aksu, Z., Öçal, M. F., Şenel, E. Ö., Konyalığlu, A. C., Hizarc1, S., \& Kaplan, A. (2011). Secondary school mathematics teachers' approaches to students' possible mistakes. Procedia Social and Behavioral Sciences, 15, 25692573. https://doi.org/10.1016/j.sbspro.2011.04.147

Ertaş, F. G., \& Aslan-Tutak F. (2015). Secondary mathematics teacher candidates' pedagogical content knowledge and the challenges to measure it. In K. Krainer \& N. Vondrová (Eds.) (2015). Proceedings of the Ninth Conference of the European Society for Research in Mathematics Education (CERME9, 4-8 February 2015) (pp. 2628-2634). Prague, Czech Republic: Charles University in Prague, Faculty of Education and ERME. Ertaş, G. \& Aslan-Tutak, F. (2017). Comparison of Mathematical Knowledge for Teaching (MKT) of Mathematics Teacher Candidates with TEDS-M Items, Inonu University Journal of the Faculty of Education, 18(3), 86-102. https://doi.org/10.17679/inuefd.355687

Hacısalihoglu Karadeniz, M., Baran, T., Bozkuş, F., \& Gündüz, N. (2015). İlköğretim Matematik Öğretmeni Adaylarının Yansıma Simetrisi ile İlgili Yaşadıkları Zorluklar. Turkish Journal of Computer and Mathematics Education, 6(1), 117-138. Hill, H. C., Rowan, B., \& Ball, D. L. (2005). Effects of teachers' mathematical knowledge for teaching on student achievement. American Educational Research Journal, 42(2), 371-406. https://doi.org/10.3102/00028312042002371

Kılıç, H., (2010). The nature of preservice mathematics teachers' knowledge of students. World Conference on Learning, Teaching and Administration (WCLTA), Egypt.

Krauss, S., Baumert, J., \& Blum, W. (2008). Secondary mathematics teachers' pedagogical content knowledge and content knowledge: validation of the COACTIV constructs. ZDM Mathematics Education, 40(5), 873-892. https://doiorg.sire.ub.edu/10.1007/s11858-008-0141-9

Mercan, F. Ç. (2013). Turkish physics teachers' views about the 2007 
physics teaching program and its implementation. Educational Research and Reviews, 8(17), 1559-1573. https://doi.org/ 10.5897/ERR2013.1564

Milli Eğitim Bakanlı̆̆ı (2018). 2023 Eğitim Vizyonu. http://2023vizyonu.meb.gov.tr/

National Council of Teachers of Mathematics (NCTM). 2000.

Principles and standards for school mathematics: An overview. NCTM.

Özoğlu, M.,Gür, B., \& Çelik, Z. (2010). Türkiye'de öğretmen yetiştirme ve istihdam politikaları. In Bilgi çağında eğitim ve Malatya (15-16 Mayıs 2010) (pp. 583-595).

Peterson, P. (1998). Teachers' and students' cognitional knowledge for classroom teaching and learning. Educational Researcher, 17(5), 5-14. https://doi.org/10.3102/0013189X017005005

Shulman, L. S. (1986). Those who understand: Knowledge growth in teaching. Educational Researcher, 15 (2), 4-14. https://doi.org/10.3102/0013189X015002004

Tatto, M., Schwille, J., Senk, S., Ingvarson, L., Peck, R., \& Rowley, G. (2008). Teacher education and development study in mathematics (TEDS-M): Policy, practice, and readiness to teach primary and secondary mathematics. Conceptual framework. IEA.

TEDS-M International Study Center. (2009). Teacher Education Study in Mathematics (TEDS-M) 2008 Released Items: Future

Teacher Mathematics Content Knowledge and Mathematics Pedagogical Content Knowledge - Secondary.

http://www.ugr.es/ tedsm/resources/Informes/Result_Viejo/ SecundariaLiberados.pdf

Ubuz, B., \& Yayan, B. (2010). Primary teachers' subject matter

knowledge: decimals. International Journal of Mathematics

Education in Science and Technology, 41(6), 787-804.

https://doi.org/10.1080/00207391003777871

Walshaw, M. (2012). Teacher knowledge as fundamental to effective teaching practice. Journal of Mathematics Teacher Education, 15, 181-185. https://doi.org/10.1007/s10857-012-9217-0

Wilson, D. S. (2007). Measuring teacher quality for professional 
174 Ertaş \& Tutak-Mathematics Teacher Education in Turkey

entry. In D. H. Gitomer (Ed.), Measurement issues and assessment for teaching quality (1st ed.) (pp. 8-29). Sage Publications, Inc.

Yıldırım, H., Yıldırım, S., Ceylan, E., \& Yetişir, M. (2013). Türkiye perspektifinden TIMSS 2011 sonuçları. Türkiye Eğitim Derneği Tedmem Analiz Dizisi I.

Yüksek Öğretim Kurumu (YÖK). (2007). Öğretmen yetiştirmede eğitim fakülteleri modeli 1982-2007 dönemi. In Y. Kavak, A. Aydın \& S. Altun (Eds.). Öğretmen yetiştirme ve ĕgitim fakülteleri (pp. 37-85). Yüksek Öğretim Kurumu Yayını.

Güneş Ertaş is Research Assistantat Boğaziçi University, Turkey.

Fatma Aslan-Tutak is Associate Professor at Boğaziçi University, Turkey.

Contact Address: Direct correspondence concerning this article, should be addressed to the author. Postal Address: Boğaziçi Üniversitesi, Eğitim Fakültesi, Matematik ve Fen Bilimleri Eğitimi Bölümü, Bebek 34342 İstanbul, Türkiye Email: gunesertas@gmail.com 